\title{
Cholesterol Content, Fatty Acid Composition and Sensory Analysis of Deep Fried and Roasted Abon Ikan (Fish Floss/Shredded Fish Flesh)
}

\author{
A Suhaeli Fahmi* and Lukita Purnamayati \\ Fisheries Product Technology Department, Faculty of Fisheries and Marine Science, Diponegoro \\ University, Semarang, Indonesia
}

\begin{abstract}
Abon ikan (fish floss/shredded fish) commonly processed by deep frying in cooking oil after fish meat were steamed and mixed with condiments. Deep frying technique used in abon ikan processing caused high rancidity risk of abon ikan during storage. In this research, deep frying and roasting method were compared. Fresh catfish (Clarias gariepinus) were used as raw material, after steamed and mixed with condiments, then mixed dough were processed with the treatments (roasted on pan or deep fried with frying oil). Cholesterol content was tested by Bohac test. Fatty acid composition was analyzed with Gas Chromatography. Roasted abon ikan contained moisture, fat and protein about $9.94 \%, 22.39 \%$ and $29.66 \%$ respectively while fried abon ikan contained about $4.98 \%, 23.19 \%$ and $27.50 \%$ respectively. Roasted abon ikan contained cholesterol about $0.28 \mathrm{mg} / \mathrm{g}$ and fried abon ikan contained about $0.74 \mathrm{mg} / \mathrm{g}$. Fatty acid profile analysis show that in both samples unsaturated fatty acid were dominated by oleic acid and linoleic acid while saturated fatty acid were dominated by palmitic acid. Roasted abon ikan were lower in palmitic acid and oleic acid content but higher in palmitoleic acid and linoleic acid. Sensory analysis showed that roasted abon ikan gave better texture, flavor and odor while deep fried abon ikan was better in appearance.
\end{abstract}

\section{Introduction}

Abon is one of traditional ready to eat food in Indonesia. Abon or shredded meat usually processed with beef meat as raw material (so the product is defined as beef floss/shredded beef meat). In Indonesia, abon usually served with daily meal as topping for rice, rice porridge, noodle or bread. However as a ready to eat product, abon also can be consumed directly. Abon also popular in several Asian countries. In Thailand, Philippines, Malaysia and Vietnam abon is known as moo yong, mahu, serunding and thit heo kho tieu

\footnotetext{
* Corresponding author: suhaeli.fahmi@ live.undip.ac.id
} 
respectively [1]. In Nigeria it is also available similar product with abon called as danbunama [2].

Abon ikan (Fish floss/shredded fish flesh) is a product development in raw material of abon. Fish from seawater, brackish water can be used as raw material of abon ikan. Huda et al. [1] reported that in Malaysia, commercial abon which made from fish gave better hedonic sensory value compare with the other raw material (beef and chicken).

Abon ikan processing is commonly started with steaming the fish. After the fish flesh is tender enough, the fish flesh is shredded into fine particles and then mixed with condiments. Then the mixture is deep fried and stirred constantly until the mixture is dry enough [3]. Sugar is one of material used in abon. The presence of sugar in abon will cause Maillard reaction. This maillard reaction is occured between reducing sugars and amino acids. This maillard reaction will cause the brown color of the product.

Common frying process of abon ikan is deep frying. Deep frying needs a lot of number of frying oil. To reduce the amount of oil in the product, deep fried abon ikan were usually pressed and/or spinned. Deep frying technique used in abon ikan processing potentially caused high rancidity risk during storage due to large volume of frying oil used in frying process. Roasting or pan frying with only a little frying oil is an alternative process to produce abon ikan. In roasting process of abon ikan the number of palm frying oil was minimized. Palm frying oil was only used for preparing the condiments before mixing with the fish flesh. This study was aimed to compare the effect of common deep frying process with roasting process to produce abon ikan in cholesterol content, fatty acid composition and sensory value of the product.

\section{Materials and methods}

\subsection{Materials}

Fresh catfish (Clarias gariepinus) was used as raw material. Shallot, garlic, onion, brown sugar, sugar, salt, coriander, lime leaves, lime peel, lemon grass, galangal, ginger and chilli were used as condiments. Commercial palm oil was used as frying oil.

\subsection{Abon ikan (fishfloss) processing}

Fresh catfish (Clarias gariepinus) were deheaded, gilled, eviscerated and cleaned with water. Cleaned fish flesh then steamed until the fish flesh was tender. After steaming process was completed, fish flesh were collected and shredded into fine particles.

The amount of $3 \mathrm{~kg}$ steamed and shredded catfish flesh were mixed with condiments. These condiments were shallot (180 g), garlic (140 g), onion (150 g), brown sugar (300 g), sugar $(250 \mathrm{~g})$, salt (30 g), coriander ( $2 \mathrm{~g})$, lime leaves (10 pcs), lime peel (1 pc), lemon grass (5 pcs), galangal (1 pc), ginger (1 pc), and chilli (200 g). Condiments were pan fried with a little number of frying oil and ready to be mixed with steamed and shredded catfish flesh. These mixed condiments and shredded steamed catfish flesh were ready for frying or roasting in pan as treatments in this experimental research.

The frying process was done by deep frying. The mixture of fish flesh and condiments was put into frying oil after the frying oil temperature reached $150^{\circ} \mathrm{C}$. This deep frying process was done for 30 minutes and during deep frying process, abon ikan was stirred. Roasting process of abon ikan was done for 40 minutes in a pan with a little number of frying oil. After deep frying or roasting, fried and roasted abon ikan then pressed and spinned with spinner to reduce the amount of oil. 


\subsection{Chemical analysis}

Abon ikan samples were prepared for proximate analysis according to AOAC [4] method to determine the moisture, protein, fat and ash content.

Cholesterol content of abon ikan was analyzed with bohac test method by weighing 0.5 gram of sample then adding $10 \mathrm{ml}$ of $2 \% \mathrm{KOH}$ solution and incubated for 15 minutes at $80^{\circ} \mathrm{C}$. The mixture was cooled by adding $5 \mathrm{ml}$ of distilled water. Then the mixture was washed twice using $10 \mathrm{ml}$ of solvent respectively. The extract obtained then heated at $45^{\circ} \mathrm{C}$ to remove the solvent. The extract was then injected into HPLC (Shimadzu, Japan) [5] [6].

The composition of fatty acid in abon ikan was analyzed with gas chromatography (Shimadzu, Japan) based on Al-Bachir and Sahloul [7], using gas chromatography (Shimadzu, Japan) supplemented with capillary columns (Shimadzu, Japan). The flame ionization detector was set at $250^{\circ} \mathrm{C}$, while the oven temperature was $190^{\circ} \mathrm{C}$ and the injector was $220^{\circ} \mathrm{C}$. The sample was injected as much as $1 \mu \mathrm{l}$. Fatty acids were identified by comparing the retention time of a sample with the retention time of fatty acid standard.

\subsection{Color analysis}

Color analysis of abon ikan were measured with chromameter Konica Minolta CR-400. Colorimetric data read were $\mathrm{L}^{*}$ (lightness), $\mathrm{a}^{*}$ (redness) and $\mathrm{b}^{*}$ (yellowness).

\subsection{Sensory analysis}

Sensory evaluation of deep fried and roasted abon ikan carried out with 30 panels. They are students from Fisheries Product Technology Department Faculty of Fisheries and Marine Science Diponegoro University. Hedonic scale method in 5 points range were used to analyze the appearance, odor, flavor, texture and overall value from panels. These 5 points were ranged from 1 (dislike very much) until 5 (like very much).

\subsection{Statistical analysis}

The data in this study were analyzed with independent sample t test to compare between treatments using software SPSS 17. Significant differences were obtained when the sig. (2tailed) $<0.05$.

\section{Results and discussion}

\subsection{Proximate analysis}

Moisture, protein, fat and ash content of both abon ikan is listed in Table 1. Roasted abon ikan had less number of moisture content (4.98\%) compare with deep fried abon ikan (9.94\%). Less number of moisture content in roasted abon ikan was related with the higher temperature during roasting process $\left(200^{\circ} \mathrm{C}\right)$ compared to the temperature of deep frying process $\left(170^{\circ} \mathrm{C}\right)$. Similar moisture content, ranged between $8.60 \%-12.15 \%$, in deep fried abon ikan also reported in commercial abon ikan in Malaysia [1].

Based on dry base proximat analysis, protein and ash content of deep fried abon ikan were higher $(\mathrm{p}<0.05)$ than roasted abon ikan while fat content did not different $(\mathrm{p}<0.05)$. Moisture content of deep fried abon ikan did not fulfill the Indonesian standard. Indonesian standard for abon as stated in SNI No. 3707:2013, define that maximum moisture, fat and ash content in abon are 7\%,30\% and 7\% respectively. Protein content in both products (32.93\% and $28.94 \%$ ) were comply the Indonesian Standard (minimum 15\%). 
Table 1. Proximate composition of deep fried and roasted abon ikan

\begin{tabular}{|l|c|c|}
\hline & Deep Fried & Roasted \\
\hline Moisture $(\% \mathrm{wb})$ & $9.94 \pm 0.14^{\mathrm{a}}$ & $4.98 \pm 0.01^{\mathrm{b}}$ \\
\hline Protein $(\% \mathrm{db})$ & $32.93 \pm 0.07^{\mathrm{a}}$ & $28.94 \pm 0.48^{\mathrm{b}}$ \\
\hline Fat $(\% \mathrm{db})$ & $24.86 \pm 0.27^{\mathrm{a}}$ & $24.41 \pm 0.52^{\mathrm{a}}$ \\
\hline Ash $(\% \mathrm{db})$ & $6.67 \pm 0.02^{\mathrm{a}}$ & $4.68 \pm 0.13^{\mathrm{b}}$ \\
\hline
\end{tabular}

Results are means \pm standard deviation

Results with the same superscript in the same row are not significantly different $(\mathrm{p}<0.05)$

\subsection{Cholesterol content}

Cholesterol content in deep fried abon ikan was lower than roasted abon ikan. This lower amount of cholesterol was related with the absorption of cholesterol from catfish flesh to frying oil during the frying process [8]. Cholesterol content of palm oil is low [9], and the cholesterol content of catfish flesh is $11.04 \%$ [10]. In addition, cholesterol content in deep fried abon ikan has decreased due to oxidation [11]. The pressing process after the deep frying which aims to reduce the oil content of abon ikan contributes significantly in reducing the amount cholesterol. In roasted abon ikan, the amount of cholesterol was higher than deep fried one because the cholesterol content in catfish flesh may not be reduced, only a portion of cholesterol undergoes oxidation during the heating process which results in Cholesterol Oxidation Product (COP) [10]. This is also related to the fat content of abon $i k a n$ where the fat content in roasted abon ikan was greater than deep fried abon ikan.

Table 2. Cholesterol content, free fatty acid and acid number of deep fried and roasted abon ikan

\begin{tabular}{|l|c|c|}
\hline & Deep Fried & Roasted \\
\hline Cholesterol content $(\mathrm{mg} / \mathrm{g})$ & $0.28 \pm 0.05^{\mathrm{a}}$ & $0.74 \pm 0.06^{\mathrm{b}}$ \\
\hline Free fatty acids $(\%)$ & $2.09 \pm 0.13^{\mathrm{a}}$ & $2.33 \pm 0.45^{\mathrm{b}}$ \\
\hline Acid numbers $(\mathrm{mg} / \mathrm{g})$ & $12.80 \pm 1.63^{\mathrm{a}}$ & $11.75 \pm 0.15^{\mathrm{a}}$ \\
\hline
\end{tabular}

Results are means \pm standard deviation

Results with the same superscript in the same row are not significantly different $(\mathrm{p}<0.05)$

\subsection{Fatty acid analysis}

Fatty acid composition (Table 3) reported that dominant fatty acid in abon ikan were palmitic acid, oleic acid and linoleic acid. Free fatty acids (FFAs) are products of lipolysis that indicate the quality deterioration of fat. FFA on roasted abon ikan is larger than deep 
fried because of the longer time of roasting process. The lipolysis process affects the oxidation process due to the presence of unsaturated fatty acids and cholesterol [8].

Table 3. Fatty acid composition of deep fried and roasted abon ikan

\begin{tabular}{|l|c|c|}
\hline Fatty acid compounds & Deep fried & Roasted \\
\hline Lauric acid $(\% \mathrm{db})$ & 0.31 & 0.34 \\
\hline Myristic acid $(\% \mathrm{db})$ & 1.83 & 1.90 \\
\hline Palmitic acid $(\% \mathrm{db})$ & 50.04 & 52.60 \\
\hline Palmitoleic acid $(\% \mathrm{db})$ & 3.34 & 1.2 \\
\hline Stearic acid $(\% \mathrm{db})$ & 4.41 & 3.56 \\
\hline Oleic acid $(\% \mathrm{db})$ & 35.33 & 35.86 \\
\hline Linoleic acid $(\% \mathrm{db})$ & 13.06 & 10.49 \\
\hline Linolenic acid $(\% \mathrm{db})$ & 0.17 & 0.3 \\
\hline Arachidic acid $(\% \mathrm{db})$ & 0.19 & 0.21 \\
\hline Behenic acid $(\% \mathrm{db})$ & 0.03 & 0.03 \\
\hline
\end{tabular}

Palm oil contains palmitic acid, stearic acid, linoleic acid and oleic acid. The largest percentage of fatty acid in palm oil are palmitic acid and oleic acid [12, 13]. In catfish flesh the dominant unsaturated fatty acids are oleic acid, linoleic acid, linolenic acid, EPA and DHA [10]. During the roasting process, there is a decrease in unsaturated fatty acids, especially palmitoleic, linoleic, and linolenic acids. This is due to the oxidation process during roasting due to longer time in high temperatures. Fatty acids that have double bonds will be more easily oxidized than those without double bonds. Linoleic fatty acids are more easily oxidized than palmitic acid because of the double bond [12].

\subsection{Color analysis}

Color analysis results shown in Table 4. Roasting process of abon ikan gave the darker color of product than deep frying process. Longer time of high temperature processing in roasting to get the desirable texture affecting the darker color of abon. Desirable color of abon is golden brown [1]. Brown color of abon is obtained from the maillard and caramelization reactions. Liao et al [1] reported that the lower frying temperature of pork floss caused the color of the product to be lighter. Color analysis of pork floss fried at $150^{\circ} \mathrm{C}, 125^{\circ} \mathrm{C}$ and $100^{\circ} \mathrm{C}$ gave the lightness value result $41.62,55.93$ and 60.99 respectively. 
Table 4. Color analysis of deep fried and roasted abon ikan

\begin{tabular}{|c|c|c|}
\hline & Deep Fried & Roasted \\
\hline Lightness & $43.33 \pm 2.78^{\mathrm{b}}$ & $41.42 \pm 0.08^{\mathrm{a}}$ \\
\hline Redness & $9.91 \pm 1.20^{\mathrm{a}}$ & $10.70 \pm 0.08^{\mathrm{b}}$ \\
\hline Yellowness & $12.80 \pm 1.63^{\mathrm{a}}$ & $11.75 \pm 0.15^{\mathrm{a}}$ \\
\hline
\end{tabular}

Results are means \pm standard deviation

Results with the same superscript in the same row are not significantly different $(\mathrm{p}<0.05)$

\subsection{Sensory analysis}

Hedonic sensory analysis results shown in Table 5. Deep fried abon ikan was better in appearance than roasted one. Panelists gave higher score in appearance of deep fried abon ikan. Color of deep fried abon ikan was golden brown as the panelists' perspective of common abon in the market.

Roasted abon ikan was better than deep fried abon ikan in odor, flavor and texture. Overall hedonic score also showed that panelists choose roasted abon ikan as the better product compare with deep fried abon ikan.

Table 5. Hedonic score of deep fried and roasted abon ikan

\begin{tabular}{|l|c|c|}
\hline & Deep Fried & Roasted \\
\hline Appearance & $4.63 \pm 0.56^{\mathrm{b}}$ & $4.43 \pm 0.63^{\mathrm{a}}$ \\
\hline Odor & $4.40 \pm 0.50^{\mathrm{a}}$ & $4.57 \pm 0.50^{\mathrm{b}}$ \\
\hline Flavor & $4.10 \pm 0.66^{\mathrm{a}}$ & $4.27 \pm 0.52^{\mathrm{b}}$ \\
\hline Texture & $4.07 \pm 0.64^{\mathrm{a}}$ & $4.60 \pm 0.67^{\mathrm{b}}$ \\
\hline Overall & $4.30 \pm 0.36^{\mathrm{a}}$ & $4.47 \pm 0.32^{\mathrm{a}}$ \\
\hline
\end{tabular}

Results are means \pm standard deviation $(\mathrm{n}=30)$

Results with the same superscript in the same row are not significantly different $(\mathrm{p}<0.05)$

\section{Conclusion}

Longer time in roasting process caused lower moisture content, higher cholesterol content and darker appearance in roasted abon ikan. Hedonic sensory analysis shows that roasted abon ikan gave better odor and texture compare to the deep fried abon ikan while deep fried abon ikan was better in appearance.

\section{References}

1. N. Huda, Y. Fatma, A. Fazillah, F. Adzitey. Pak. J. Nutr. 11(1), 1-4 (2012)

2. O. O. Ogunsola, A. B. Omojola. Pak. J. Nutr. 7, 554-556 (2008)

3. L. Fachruddin, Teknologi tepat guna: Membuat aneka abon (Penerbit Kanisius, Yogyakarta, 1997) 
4. AOAC, Official methods of analysis (Association of Official Analytical Chemist, Washington DC, 2005)

5. N. Bragagnolo, D. B. Rodriguez-Amaya. Journal of Food Composition and Analysis. 16, 147-153 (2003)

6. H. Osman, Y. K. Chin. The Malaysian Journal of Analytical Sciences. 10(2), 205-210 (2006)

7. M. Al-Bachir, H. Sahloul. International Journal of Food Properties. 20(11), 2550-2558 (2017)

8. M. Echarte, M. A. Zulet, I. Astiasaran. J. Agric. Food. Chem. 49, 5662-5667 (2001)

9. J. Okpuzor, V. I. Okochi, H. A. Ogbunugafor, S. Ogbonnia, T. Fagbayi, C. Obidiegwu. Pak. J. Nutr. 8, 57-62 (2009)

10. R. Rosa, N. M. Bandarra, M. L. Nunes. Inter. J. Food. Sci. Tech. 42, 342-351 (2007)

11. S. Al-Saghir, K. Thurner, K. H. Wagner, G. Frisch, W. Luf, E. R. Fazeli, I. Elmadfa. J. Agric. Food. Chem. 52, 5290-5296 (2004)

12. O. O. Abiona, S. H. Awojide, A. J. Anifowoshe, O. B. Babalola. E. Inter. Sci. Research. J. 3, 210 (2011)

13. O. B. Imoisi, G. E. Ilori, I. Agho, J. O. Ekhator. J. Appl. Sci. Environ. Manage. 19, 127 133 (2015)

14. G. Liao, X. Xu and G Zhou. Journal of Food Processing and Preservation. 33(2), 159175 (2009) 